\title{
Domestic Fuel Price and Economic Sectors in Malaysia
}

\author{
Hui-Siang JEE Brenda, Evan LAU*, Chin-Hong PUAH, Shazali ABU MANSOR \\ Departments of Economics, Faculty of Economics and Business, Universiti Malaysia Sarawak, 94300 Kota \\ Samarahan, Sarawak, Malaysia \\ lphevan@feb.unimas.my
}

\begin{abstract}
This study empirically examines the relation between the domestic fuel prices with the ten disaggregated economic sectors in Malaysia with the spanning of data from 1990:Q1 to 2007:Q4. We found that only three sectors (agriculture, trade and other services sectors) are cointegrated with the fuel price and fuel price does Granger cause these sectors. Despite the evidence of non-cointegrated in most of the economic sectors, fuel price able to influence these sectors over a longer period. Policy recommendation from this study includes the utilization of the renewable energy (RE) as a strategic plan is the long-term solution due to the high dependency and increasing demand of energy. While energy prices have experienced some correction in response to signs of slower global growth, sufficient government enforcement and support need to be established to facilitate successful renewable energy implementation in Malaysia.
\end{abstract}

Keywords: Fuel price, Economic sector, Granger causality, Renewable Energy, Growth

\section{Introduction and Literature}

Since the discovery of crude oil, it has been plays an important role in the development of the world economy. The transformation of the crude oil to the variety of energy products such as diesel, gasoline, kerosene, butane prove it is a vital source of energy, an irreplaceable transport fuel and an essential raw material in many manufacturing processes (Chang and Wong, 2003). Hamilton (1983) in his seminal work found that that oil prices have strongly correlated with real economic activity in the United States since World War II ${ }^{1}$. As the movement of crude oil prices fluctuates and volatile, it creates uncertainty, leading to economic instability for both oil-exporting and oil-importing countries (Narayan and Narayan, 2007).

The transmission mechanisms through which oil prices have an impact economic activity include (1) supply channel and, (2) demand channel2 ${ }^{2}$. For the supply side, the increase of oil price is likely to transfer higher cost to the producer. As a result, the producer reduces their energy spending by consuming less energy. With the productivity inefficiency, the production output falls. Additionally, Hamilton (1988) indicates that the relative changes in prices have caused the unemployment rate to increase. When the oil prices increase, the demand for labor in the severely affected sector has reduced due to the contraction in production. With such constrain, the productivity inefficiency in the end has lower down the output growth. Through the demand side channel, the increase of oil prices has redistributed the income from oil-importing country to oil-exporting country (Ferderer, 1996). Accordingly, the disposal income in the oil-importing country decelerates and finally depresses the aggregate demand as the purchasing power has reduced. In this unfavorable environment, the investor is likely to postpone the investment, as the future economic performance is uncertain (Bernanke, 1983) and it slower the investment activity.

\footnotetext{
${ }^{1}$ The episodes of oil price shocks since 1973 give rise to a plethora of studies devoted to this branch of literature (see for example, Hamilton, 1983, 1996; Gisser and Goodwin, 1986; Mork, 1989; Kim and Loungani, 1992; Ferderer, 1996; Papapetrou, 2001; Brown and Yucel, 2002; Cunado and de Gracia, 2003, 2005; JiménezRodriguez and Sánchez, 2005; Raguindin and Reyes, 2005 and Farzanegan and Markwardt, 2009).

${ }^{2}$ It is worth noting that there are other transmission mechanism discuss in the literature. This includes the real balances; role of monetary policy, the foreign exchange markets and inflation (see for example Ferderer, 1996; Brown and Yucel, 2002; Jiménez-Rodriguez and Sánchez, 2005 and Raguindin and Reyes, 2005) which give rise to indirect on real economic activity.
} 
Therefore, an understanding of the oil price movement ${ }^{3}$ is crucial because persistent and long lasting changes can expose producers and industrial consumers to risk, thus affecting investments in oil inventories and facilities for production and transportation. This matter worsens if oil were the only main source of energy in a country.

In Malaysia, it has been largely used as the intermediate inputs in the industrial production activity around 40 percent in 2005 (EPU, 2006). Amongst the types of energy sources, petroleum products are the highly demanded that constitute more than 60 percent of total energy consumption in 2005. This creates an environment of uncertainty as the high dependency on petroleum products kept Malaysia at risk if the international crude oil price remains high.

Although the government practices fuel subsidies and tax exemption mechanism where the price is considered as the lowest amongst the Southeast Asian countries after Brunei (NEAC, 2005), the rise of international crude oil price is likely burdening the government. In order to lighten the burden, the Malaysian government has revised its fuel prices several times in between year 2000 to 2008. For example, the 18.5 percent rises in fuel price in February 2006 (from RM1.62 to RM1.92) has reduced the total expenditure on fuel subsidy and tax exemption, which drop from RM 16 billions in 2005 to RM 14.7 billions in 2006. In early June 2008 the government increases the domestic petrol fuel price to RM2.70 due to the significant increase of the world crude oil. By August 23, 2008 the domestic petrol price to RM2.55 per liter after considering the drop in global oil prices over the past month as well as higher inflation in July. By the end of 2008, the price of RON97 petrol is was reduced further to RM1.80, while RON92 is selling at RM1.70 a liter. The pump price of diesel was reduced to RM1.70 a liter. From September 2009 however, the price for RON97 increased to RM2.05, while the RON92 has been discontinued and replaced with RON95, at a price of RM1.80. In July 2010, the RON95 price was raised from RM1.80 to RM1.85 while R0N97 price increased from RM2.05 to RM2.10 while diesel from RM1.70 to RM1.75. By May of 2011, RON97 were priced at RM2.90 and in June dropped to RM2.80 per liter as response to drop in world oil price.

With the motivation in place, this study empirically examined the relation between the domestic petrol price and the disaggregated economic sectors in Malaysia. The present paper extends the existing empirical literature in two directions. First, this paper use Malaysia ${ }^{4}$, oil-exporting countries rather than most of the existing literature that focuses on the oil-importing countries ${ }^{5}$. A study by Jiménez-Rodriguez and Sánchez (2005) found that oil price shocks do not bring benefit to UK, one of the oil-exporter countries. Second, we considered the effect of oil prices on ten disaggregated economic sectors in Malaysia ${ }^{6}$. The advantage of using disaggregated data is to see whether fluctuation of the prices will leave

\footnotetext{
${ }^{3}$ A look into the chronological movement of oil prices perceived that the previous steep rise in oil prices is due to the supply disruption, but in the past few years it is no longer the main factor of the oil price fluctuations. Rather, the increasing demand from the Asian countries, especially China plus the large consumption from the US have caused oil price to surge. For example, prices increased rapidly in the millennium from a low price of US $\$ 19$ per barrel in 1999 to US $\$ 35$ and reaching above $\$ 40$ by the end of 2004. By mid-2005, the price goes beyond US $\$ 50$ per barrel and rocketing to nearly US $\$ 90$ per barrel in 2007. On the eve of 2008, a single trade was made at US $\$ 100$. Oil prices broke through US $\$ 110$ on March 2008 and by June 2008 stood at US $\$ 145$. On early July 2008, oil prices rose to a new record of US $\$ 147$. However, oil prices declined to US $\$ 125$ a barrel by the end of July. A strong contributor to this price decline is the drop in domestic demand for oil. By 2009 2010 , prices were fluctuated around US $\$ 38$ - US $\$ 85$ and recently in July 2011 , prices were around US $\$ 100$ per barrel.
}

\footnotetext{
${ }^{4}$ Malaysia is ranked number 23 in 2006 as a net oil-exporter (see EIA, International Petroleum Monthly, various issues).

${ }^{5}$ Despite being an oil-exporter since 1970s, the increasing domestic oil demand and limited reserve condition, the probing question of sustaining its oil exporting status is rather important (Gan and $\mathrm{Li}, 2008$ ). Although the issue is beyond the paper, it is of great concern to Malaysia.

${ }^{6}$ According to Department of Statistics (DOS) Malaysia's classification, the Malaysian economic activity can be divided into 10 major sectors, including agriculture, forestry and fishing, mining and quarrying, manufacturing, construction, electricity, water and gas, transport, storage and transportation, wholesale and
} 
any consequences on any particular economic sectors in Malaysia ${ }^{7}$. Although some researchers do suggest that an oil price increase would be beneficial for an oil exporter as a whole, like the reduction of total expenditure in Malaysia, the effects on specific economic sectors remained ambiguous, as the heterogeneity effects may exist across economic sectors. In this sense, manipulation of appropriate policy conclusion on the different economic sector would be able to materialize.

The following is the organization of this paper: Section 2 describes the data and methodology for the study. Section 3 discusses the empirical results and finally, Section 4 presents the concluding remarks.

\section{Data Description and Econometric Strategy}

Data Description: Quarterly data spanning from 1990:Q1 to 2007:Q4 consist of 72 observations were adopted in this study ${ }^{8}$. Table 1 summarized the 11 variables used in this study where domestic fuel price ${ }^{9}$ has been obtained from Ministry of Domestic Trade and Consumer Affairs while the 10 economic outputs are compiled from Monthly Statistical Bulletin published by Bank Negara Malaysia. All the variables are all expressed in log terms and converted into real terms (except for fuel prices) by using the consumer price index (CPI) and were expressed in domestic currency prior to estimation.

\section{Table 1: List of Variables}

\begin{tabular}{ll}
\hline Variable & Description \\
\hline lfuel & Natural logarithm of fuel prices \\
lragri & Natural logarithm of real agriculture, forestry and fishing output \\
lrmin & Natural logarithm of real mining and quarrying output \\
lrmfc & Natural logarithm of real manufacturing output \\
lrcons & Natural logarithm of real construction output \\
lrutilities & Natural logarithm of real electricity, gas and water output \\
lrtrade & Natural logarithm of real wholesale and retail trade, accommodations and \\
& restaurants output \\
lrtransport & Natural logarithm of real transport, storage and transportation output \\
lrfin & Natural logarithm of real finance, insurance, real estates and business services \\
& output \\
lrgov & Natural logarithm of real government services output \\
lroth & Natural logarithm of real other services output \\
\hline
\end{tabular}

Unit Root and Stationary Testing Procedures: We adopted the Said and Dickey (1984, ADF), Elliott et al. (1996, DFGLS) and Kwiatkowski et al. (1992, KPSS) testing principles in this study. The ADF and DFGLS share the same null hypothesis of a unit root while KPSS procedure tests for level $\left(\eta_{\mu}\right)$ or trend stationarity $\left(\eta_{\tau}\right)$ against the alternative of a unit root. In this sense, the KPSS principles involve different maintained hypothesis from the ADF and DFGLS unit root tests.

retail trade, hotels and restaurants, finance, insurance and real estates and business services, government services and other services.

${ }^{7}$ Studies focuses on the impact of oil price shocks to sectoral performances are increasingly available in the literature (see for example, Bauer and Byrne, 1991; Zind, 1999; Schintke, et al., 2000; Valadkhani and Mitchell, 2001; Jiménez-Rodriguez, 2007; Saari, et al., 2008).

${ }^{8}$ We acknowledge the concern of the referee on the estimation period $(1990-2007)$ which includes the 1997 Asian financial crisis. As the paper focus on the domestic oil price and disaggregated economic activity, the issue drastic shift in global economic activities were not considered in the paper, in which future study would pursue. Moreover, the domestic oil price in Malaysia was controlled by the government through subsidy (Abdul Jalil, et al., 2009).

${ }^{9}$ This is another extension of the literature on this branch of studies. Rather than looking into the international prices, we use domestic fuel prices. 
Cointegration Procedure: The system-based cointegration procedure developed by Johansen and Juselius (1990, JJ) to test the absence or presence of long run equilibrium is adopted in this paper ${ }^{10}$. One advantage of this approach is that the estimation procedure does not depend on the choice of normalization and it is much more robust than Engle-Granger test (see Gonzalo, 1994). Phillips (1991) also documented the desirability of this technique in terms of symmetry, unbiasedness and efficiency. Their test utilizes two likelihood ratio (LR) test statistics for the number of cointegrating vectors: namely the trace test and the maximum eigenvalue test. As the JJ procedure is well known in the time series literature and the detail explanation are not presented here.

Granger Causality Tests: If cointegration is detected, then the Granger causality should be conducted in vector error correction model (VECM) to avoid problems of misspecification (see Granger, 1988). VECM is a special case of VAR that imposes cointegration on its variables where it allows us to distinguish between short run and long run Granger causality. The relevant error correction terms (ECTs) must be included in the VAR to avoid misspecification and omission of the important constraints. The existence of a cointegrated relationship in the long run indicates that the residuals from the cointegration equation can be formulated as follows:

$$
\begin{aligned}
& \Delta E S_{t}=\alpha_{0}+\sum_{i=1}^{m} \beta_{1, i} \Delta E S_{t-i}+\sum_{i=1}^{n} \beta_{2, i} \Delta F U E L_{t-i}+\mu_{1} E C T_{t-1}+\zeta_{1 t} \\
& \Delta F U E L_{t}=\delta_{0}+\sum_{i=1}^{n} \phi_{1, i} \Delta F U E L_{t-i}+\sum_{i=1}^{m} \phi_{2, i} \Delta E S_{t-i}+\mu_{2} E C T_{t-1}+\zeta_{2 t}
\end{aligned}
$$

where $\Delta$ is the lag operator, $\alpha_{0}, \delta_{0}, \beta$ s and $\phi^{\prime} \mathrm{s}$ are the estimated coefficients, $m$ and $n$ are the optimal lags of the series ES and FUEL, $\zeta_{i t}$ 's are the serially uncorrelated random error terms while $\mu_{1}$ and $\mu_{2}$ measure a single period response of the ES (FUEL) to a departure from equilibrium. ES refer to the relevant disaggregate economic sectors in Malaysia while FUEL is the domestic fuel price. To test whether FUEL does not Granger cause movement in ES, $\mathrm{H}_{0}: \beta_{2, i}=0$ for all $i$ and $\mu_{1}=0$ in Equation (1) ${ }^{11}$. The rejection implies that FUEL causes ES. Similar analogous restrictions and testing procedure can be applied in testing the hypothesis that ES does not Granger cause movement in FUEL where the null hypothesis $\mathrm{H}_{0}: \phi_{2, i}=0$ for all $i$ and $\mu_{2}=0$ in Equation (2). In the case where cointegration is absence, the standard first difference vector autoregressive (VAR) model is adopted. This simpler alternative of causality is feasible through the elimination of ECT from both equations above. In other words, it only contains the short run causality information.

Generalized Variance Decomposition (GVDCs): In order to gauge the relative strength of the variables and the transmission mechanism responses, we shock the system and partition the forecast error variance decomposition (FEVD) for each of the variables in the system. However, the results of FEVD based on Choleski's decomposition are generally sensitive to the ordering of the variables and the lag length (see Lutkepohl, 1991). In this paper, the Generalized Variance Decomposition (GVDCs) suggested by Lee et al. (1992) is applied here. The innovation of the GVDCs will be represented in percentage form and strength of two variables to their own shocks and each other are measure by the value up to 100 percent. The GVDCs are executed using time horizons of 1 up to 24 quarters.

\section{Empirical Results and Discussion}

Unit Root Analysis: For this purpose, we conduct two unit root and one stationary test discuss earlier on the series of $\mathrm{CAD}$ and $\mathrm{BD}$ and their first differences in order to discriminate the conclusion of stationarity

\footnotetext{
${ }^{10}$ Although this is more apparent for multivariate systems or relationships, the Johansen procedure has been used extensively in various bivariate studies (for example, see Masih and Masih, 1994, 1995) indicating more robust findings in contrast to the residual-based counterparts.
}

\footnotetext{
${ }^{11}$ The F-test or Wald $\chi^{2}$ of the explanatory variables (in first differences) indicates the short run causal effects ( $\beta_{2, i}=0$ for all $i$ ) while the long run causal $\left(\mu_{1}=0\right)$ relationship is implied through the significance of the lagged ECT which contains the long run information.
} 
and non-stationarity of these series. The results of ADF and DFGLS test strongly reject the null hypothesis at 95 percent confidence level. Meanwhile, the KPSS statistics further strengthened this conclusion by failing to reject the null hypothesis after taking first difference. Thus, these univariate unit root and stationary tests yield results that are consistent with the notion that all the variables are nonstationary in level but stationary in first difference (i.e., I(1). These results are not presented here, but are made available upon request from the authors.

Cointegration Test Results: Before proceed to the cointegration analysis, we identify the number of optimum lags that for the vector autoregression (VAR) system. Such a procedure is important, as the cointegration analysis is sensitive to the lags order (Hall, 1991). For the purpose of the analysis, the Shcwert (1987) approach was adopted and the chosen lags are equal to four.

The results portrays in Table 2 indicate that the null hypothesis have been rejected for both trace test and maximum eigenvalue test in Panels A and F. It implies agriculture sector and wholesale and retail trade, accommodation and restaurants sector (hereafter trade sector) are cointegrated with the fuel price in the long run. Likewise, the other services sector (Panel J) also cointegrated with fuel price although inconsistent results have been drawn from the two tests as Johansen and Juselius (1990) claim that maximum eigenvalue test has high power as compare to the trace test.

Table 2: Cointegration Test Results

\begin{tabular}{|c|c|c|c|c|c|}
\hline $\mathbf{H}_{\mathbf{0}}$ & $\mathbf{H}_{1}$ & $\begin{array}{c}\text { Trace } \\
\text { Statistic }\end{array}$ & $\begin{array}{c}95 \% \\
\text { Critical Value } \\
\end{array}$ & $\begin{array}{c}\text { Maximum-Eigenvalue } \\
\text { Statistic }\end{array}$ & $\begin{array}{c}95 \% \\
\text { Critical Value } \\
\end{array}$ \\
\hline \multicolumn{6}{|c|}{ Panel A: lragri $(\mathrm{k}=4, \mathrm{r}=1)$} \\
\hline$r=0$ & $r=1$ & $17.075^{*}$ & 15.41 & $16.679 *$ & 14.07 \\
\hline $\mathrm{r}<=1$ & $r=2$ & 0.396 & 3.76 & 0.396 & 3.76 \\
\hline \multicolumn{6}{|c|}{ Panel B: $\operatorname{lrmin}(\mathrm{k}=4, \mathrm{r}=0)$} \\
\hline$r=0$ & $r=1$ & 13.250 & 15.41 & 11.847 & 14.07 \\
\hline $\mathrm{r}<=1$ & $r=2$ & 1.402 & 3.76 & 1.402 & 3.76 \\
\hline \multicolumn{6}{|c|}{ Panel C: lrmfc $(\mathrm{k}=4, \mathrm{r}=0)$} \\
\hline$r=0$ & $r=1$ & 5.080 & 15.41 & 5.061 & 14.07 \\
\hline $\mathrm{r}<=1$ & $r=2$ & 0.019 & 3.76 & 0.019 & 3.76 \\
\hline \multicolumn{6}{|c|}{ Panel D: lrcons $(\mathrm{k}=4, \mathrm{r}=0)$} \\
\hline$r=0$ & $r=1$ & 10.296 & 15.41 & 10.190 & 14.07 \\
\hline $\mathrm{r}<=1$ & $r=2$ & 0.106 & 3.76 & 0.106 & 3.76 \\
\hline \multicolumn{6}{|c|}{ Panel E: lrutilities $(\mathrm{k}=4, \mathrm{r}=0)$} \\
\hline$r=0$ & $r=1$ & 6.940 & 15.41 & 6.533 & 14.07 \\
\hline $\mathrm{r}<=1$ & $r=2$ & 0.407 & 3.76 & 0.407 & 3.76 \\
\hline \multicolumn{6}{|c|}{ Panel F: lrtrade $(\mathrm{k}=4, \mathrm{r}=1)$} \\
\hline$r=0$ & $r=1$ & $29.991^{*}$ & 15.41 & $29.312^{*}$ & 14.07 \\
\hline $\mathrm{r}<=1$ & $r=2$ & 0.679 & 3.76 & 0.679 & 3.76 \\
\hline \multicolumn{6}{|c|}{ Panel G: lrtransport $(\mathrm{k}=4, \mathrm{r}=0)$} \\
\hline$r=0$ & $r=1$ & 5.935 & 15.41 & 5.880 & 14.07 \\
\hline $\mathrm{r}<=1$ & $r=2$ & 0.055 & 3.76 & 0.055 & 3.76 \\
\hline \multicolumn{6}{|c|}{ Panel H: lrfin $(\mathrm{k}=4, \mathrm{r}=0)$} \\
\hline$r=0$ & $r=1$ & 7.299 & 15.41 & 7.290 & 14.07 \\
\hline $\mathrm{r}<=1$ & $r=2$ & 0.008 & 3.76 & 0.008 & 3.76 \\
\hline \multicolumn{6}{|c|}{ Panel I: $\operatorname{lrgov}(\mathrm{k}=4, \mathrm{r}=0)$} \\
\hline$r=0$ & $r=1$ & 9.184 & 15.41 & 5.832 & 14.07 \\
\hline $\mathrm{r}<=1$ & $r=2$ & 3.352 & 3.76 & 3.352 & 3.76 \\
\hline \multicolumn{6}{|c|}{ Panel J: lroth $(\mathrm{k}=4, \mathrm{r}=1)$} \\
\hline$r=0$ & $r=1$ & 15.049 & 15.41 & $15.045^{*}$ & 14.07 \\
\hline $\mathrm{r}<=1$ & $r=2$ & 0.005 & 3.76 & 0.005 & 3.76 \\
\hline
\end{tabular}

Notes: Asterisk $\left(^{*}\right)$ indicates statistically significant at 5 percent level, while the $\mathrm{k}$ is the lag length and $r$ represents the number of cointegrating vector.

However, we do not find any significant long run relationship between fuel price and the remaining economic sectors, as the null hypothesis has not been rejected. As such, this implies that the mining sector, manufacturing sector, construction sector, electricity and gas and water sector (utilities sector), 
transport, storage and transportation sector (transportation sector), finance, insurance, real estate and business services sector (finance sector) and government services sector do not cointegrated with the fuel price. Hence, the inferences that we can draw from these results is most of the economic sectors in Malaysia is unlikely to have a long run relationship with the domestic fuel price.

Temporal Causality Results: VECM: The results presented in Table 3 are the temporal causality estimates in VECM. First, economic sectors (Iragri, lrtrade and lroth) are found to be endogenous in the system. This is shown in economic sectors equation where the ect is statistically significant suggesting that this three sectors solely bears the brunt of short run adjustment to bring about the long run equilibrium. Second, the $t$-statistics on the lagged residual are statistically significant and negative in all the economic sectors supporting the cointegration results reported in Table 2. Third, we found that the speed of adjustment as measured by the ect coefficient to long run equilibrium following a disturbance ranging from 0.047 (lroth) to 0.206 (lragri). The magnitude of these coefficients indicates that the speed of adjustment towards the long-run path varies among these three cases. Specifically, agriculture sector ( 5 percent), trade sector (13 percent) and other services sector ( 21 percent) need approximately about twenty, eight and five quarters to adjust to the long run equilibrium due to the short run adjustments.

Table 3: Temporal Causality Results $(\mathrm{k}=4)$

\begin{tabular}{lccc}
\hline Dependent variable & \multicolumn{2}{c}{ Chi-square statistics } & Coefficients \\
\hline Panel A & $\Delta$ lragri & $\Delta$ lfuel & ect \\
\hline$\Delta$ lragri & - & $9.542(0.023)^{*}$ & $-0.206[-4.047]^{*}$ \\
$\Delta$ lfuel & $1.672(0.643)$ & - & $-0.003[-0.178]$ \\
\hline Panel B & $\Delta$ lrtrade & $\Delta$ lfuel & ect \\
\hline$\Delta$ Irtrade & - & $9.329(0.025)^{*}$ & $-0.128[-5.331]^{*}$ \\
$\Delta$ lfuel & $3.444(0.328)$ & - & $0.024[1.459]$ \\
\hline Panel C & $\Delta$ lroth & $\Delta$ lfuel & ect \\
\hline$\Delta$ lroth & - & $2.066(0.559)$ & $-0.047[-3.704]^{*}$ \\
$\Delta$ lfuel & $0.046(0.997)$ & - & $0.021[0.989]$ \\
\hline
\end{tabular}

Notes: Asterisk $(*)$ indicates statistically significant at 5 percent level. The values presented in square bracket [ ] and in parentheses ( ) are the t-statistics and p-values, respectively.

Fourth, the insignificant coefficient of the ect in all of the fuel price equations suggesting that the fuel price is relatively exogenous in the system. Fifth, we found that fuel price Granger cause economic sectors in Malaysia in the long run. Further, it is an evident that the null hypothesis of FUEL does not cause (in Granger-sense) ES in the short run is easily rejected at 5 percent significance level except for the lroth sector. Specifically, short run causality is absence in Panel C.

Generalized Variance Decomposition Analysis (GVDCs): Table 4 documented the decomposed forecast error variance of the two variables over the different time horizon. The value which measured in percentage in the main diagonal provide a sufficient forecasting information about to which extent the relative variance of one variable is being explained by its own shock or other variable's shocks. If it is mainly explained by its own shock, then the variable is said to be relatively exogenous.

From the reported decomposition results, it shows that the relative variance of most of the variables have been largely attributed by its own shock, especially the relative variance in fuel price. Thus, fuel price is a relatively exogenous variable comparatively to the economic sectors as time expands. For instance, in to Panel A, Table 4 less than half of the lragri variance is being explained by its own innovation as time expand to 24 quarters. This implies that the fuel price has a greater impact on agriculture sector after 24 quarters, which constituted about 83 percent. Similar results are observed in Panel B where the variation in trade sector has been largely indicated by lfuel, which constituted about 64 percent. This support the earlier causality pattern observed in Table 3. 
Table 4: Generalized Variance Decomposition Analysis (GVDCs) Results

\begin{tabular}{|c|c|c|c|}
\hline Percentage of variations in & Horizon (quarters) & Due & n in: \\
\hline Panel A: & & $\Delta$ Iragri & $\Delta$ lfuel \\
\hline Quarters relative variance in: & cagri & & \\
\hline & 1 & 94.213 & 5.787 \\
\hline & 4 & 93.340 & 6.660 \\
\hline & 8 & 87.281 & 12.719 \\
\hline & 24 & 17.321 & 82.679 \\
\hline Quarters relative variance in: & fuel & & \\
\hline & 1 & 1.349 & 98.651 \\
\hline & 4 & 2.215 & 97.785 \\
\hline & 8 & 2.247 & 97.753 \\
\hline & 24 & 2.087 & 97.913 \\
\hline Panel B: & & $\Delta$ lrtrade & $\Delta$ lfuel \\
\hline Quarters relative variance in: & trade & & \\
\hline & 1 & 98.818 & 1.182 \\
\hline & 4 & 96.848 & 3.152 \\
\hline & 8 & 90.011 & 9.989 \\
\hline & 24 & 36.061 & 63.939 \\
\hline Quarters relative variance in: & fuel & & \\
\hline & 1 & 2.101 & 97.899 \\
\hline & 4 & 3.229 & 96.771 \\
\hline & 8 & 3.892 & 96.108 \\
\hline & 24 & 5.720 & 94.280 \\
\hline Panel C: & & Alroth & $\Delta$ lfuel \\
\hline Quarters relative variance in: & roth & & \\
\hline & 1 & 99.795 & 0.205 \\
\hline & 4 & 98.749 & 1.251 \\
\hline & 8 & 98.953 & 1.047 \\
\hline & 24 & 77.596 & 22.404 \\
\hline Quarters relative variance in: & fuel & & \\
\hline & 1 & 0.121 & 99.879 \\
\hline & 4 & 0.129 & 99.871 \\
\hline & 8 & 0.251 & 99.749 \\
\hline & 24 & 1.192 & 98.808 \\
\hline
\end{tabular}

Notes: The columns in italic represent the impact of their own shock or innovation.

However, such trend is absence in Panel C, whereby major constitution of relative variance in lroth remains contributed by its own shock even up to 24 quarters. We can imply that the innovation in lroth has remained relatively exogenous but such impact may disappear in a longer time frame as the decreasing trend has been observed. In other words, the fuel price shock is able to affect the other service sector, taking into consideration of a longer time frame, supporting the long run causality existence in Table 3.

Persistence Profile Shock for Cointegrating Vector: Persistence profile of a system-wide shock is an alternative procedure to positioning the impulse response function (IRFs) introduced by Lee et al. (1992) and Lee and Pesaran 1993). It is a unique measure of the effect by the shock in estimating one-step ahead forecast error for the whole system. In other words, it shows the speed of convergence to equilibrium for a cointegrating system ${ }^{12}$. One interesting feature of this kind of experiment is that it gives a feeling for

12 This long run information obtained mimics the error correction term (ECTs) through the vector error correction model (VECM) framework applied earlier in the presence of cointegration. In addition, impulse response function (IRFs) and half-life measurement also quantify on how fast a shock occurred and when the whole process would in principle, take to complete. 
how long it takes the system to adjust back to the long run equilibrium after a real disturbance, or shock occurs.

For Figure 1a, it shows a declining trend of the cointegrating vector in moving towards the long-run equilibrium point. In other words, their response to a system-wide shock is quite marginal as their response is lower than one unit throughout the horizon. On the other hand, for Figures $1 \mathrm{~b}$ and $\mathrm{c}$, the overshooting effects have been observed in the first few quarters, whereby the cointegrating vector response higher than one unit due to the one unit shock in the system. Nevertheless, these effects tend to be eliminated after few quarters (i.e. starting from quarter seventh to quarter ninth) before reach to zero point. The three figures tend to be reverted back to its long run equilibrium point but at a slower pace of more than 20 quarters. With such evidence, we can confirm that these variables are indeed poses a longrun cointegrating relationship as suggested in cointegration analysis. Additionally, the slow restoration is likely to mirroring some time lags in response to the governmental policy adjustment.

\section{Figure 1a: Persistence Profile Shock for Cointegrating Vector (lragri)}

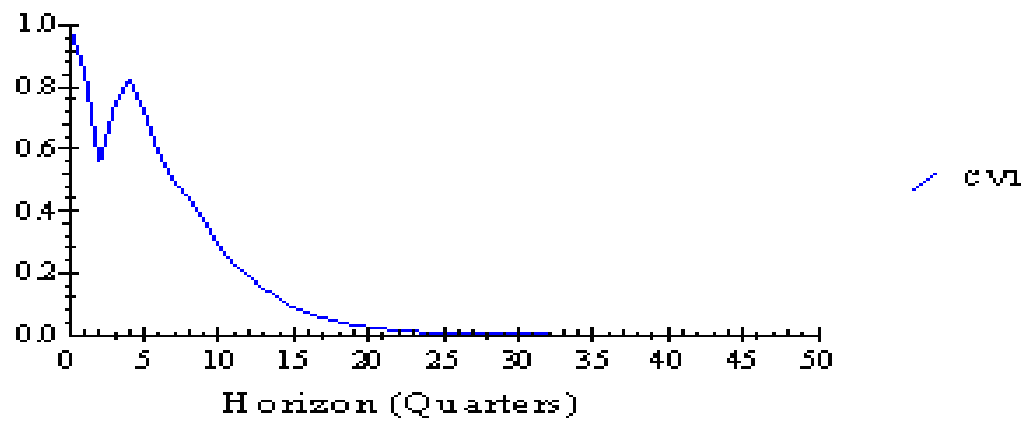

Figure 1b: Persistence Profile Shock for Cointegrating Vector (Irtrade)

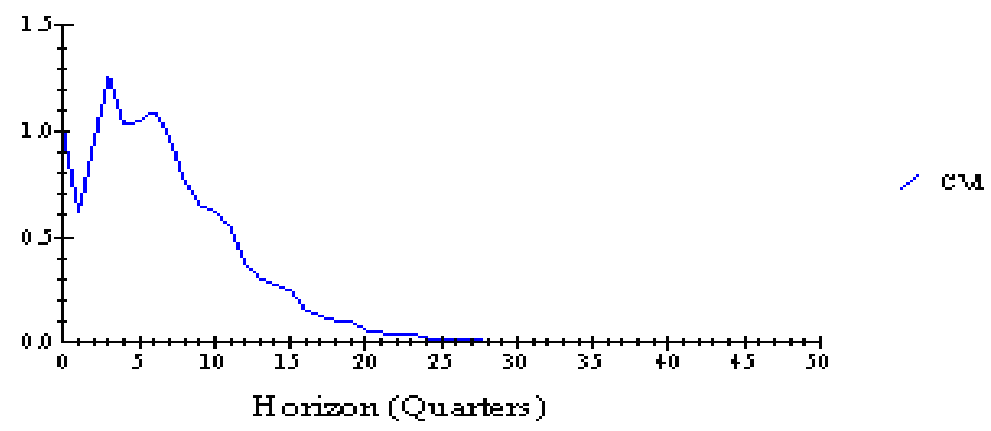

Figure 1c: Persistence Profile Shock for Cointegrating Vector (lroth)

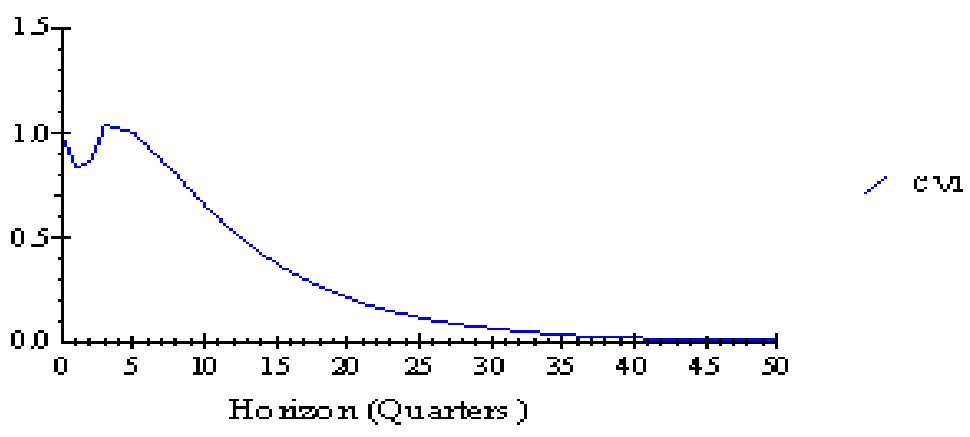

Granger Causality Test Results: Since no long run equilibrium is evident for seven other economic sectors in Table 2, hence the pair wise Granger (1969) causality test in first difference seems to be an appropriate tool. We used the lag structures from one up to four and the results are summarized in Table 5. By referring to Panel B, C, D, E and F, it shows that the F-statistics are insignificant, therefore, hinders us from rejecting the null hypothesis. As such, this implies that the fuel price does not Granger cause the 
manufacturing sector, construction sector, transportation sector and financial sector in Malaysia and vice versa in short-run. Results in Panel G indicated the existence of bidirectional causality between the fuel price and government services sector only in lag one. Therefore, we rather justify that there are no causality relationship between these variables as their relation only exist in a very short period of time.

Only in Panel A, there is a short run causality relationship running from mining sector to the fuel price. This pattern exist due to the fact that the oil companies will strive to look for more oil reserves or extract more crude oil from the previously uneconomically oil drilling fields in the case of high rise international oil prices. Accordingly, that particular sector output will increase and contribute to the greater export earnings for the country. This in turn we used to finance the domestic fuel subsidies in which the causality perceived. Therefore, in the shorter period, the Malaysian government is able to maintain its domestic fuel price and reduce the nation's burden.

Table 5: Short Run Granger Causality Results

\begin{tabular}{|c|c|c|c|c|}
\hline \multirow[t]{2}{*}{ Null Hypothesis } & Lag 1 & Lag 2 & Lag 3 & Lag 4 \\
\hline & \multicolumn{4}{|c|}{ F-Statistics } \\
\hline \multicolumn{5}{|l|}{ Panel A: } \\
\hline lfuel does not Granger cause lrmin & 0.480 & 0.798 & 0.353 & 0.347 \\
\hline Irmin does not Granger cause lfuel & $11.675^{*}$ & 7.089* & $4.179 *$ & $3.271^{*}$ \\
\hline \multicolumn{5}{|l|}{ Panel B: } \\
\hline lfuel does not Granger cause lrmfc & 0.693 & 1.171 & 0.488 & 0.459 \\
\hline lrmfc does not Granger cause lfuel & 3.593 & 1.840 & 1.351 & 1.172 \\
\hline \multicolumn{5}{|l|}{ Panel C: } \\
\hline lfuel does not Granger cause lrcons & 0.002 & 0.471 & 0.373 & 0.329 \\
\hline \multicolumn{4}{|l|}{ Panel D: } & 0.232 \\
\hline Ifuel does not Granger cause lrutilities & 0.024 & 0.152 & 0.056 & 0.036 \\
\hline Irutilities does not Granger cause lfuel & 2.181 & 1.749 & 1.194 & 0.927 \\
\hline \multicolumn{5}{|l|}{ Panel E: } \\
\hline lfuel does not Granger cause lrtransport & 0.245 & 0.759 & 0.480 & 0.329 \\
\hline $\begin{array}{l}\text { lrtransport does not Granger cause lfuel } \\
\text { Panel F: }\end{array}$ & 3.403 & 1.772 & 1.181 & 0.933 \\
\hline lfuel does not Granger cause lrfin & 1.262 & 1.233 & 0.820 & 0.693 \\
\hline Irfin does not Granger cause lfuel & 1.404 & 0.784 & 0.570 & 0.562 \\
\hline \multicolumn{5}{|l|}{ Panel G: } \\
\hline lfuel does not Granger cause lrgov & $7.848^{*}$ & 2.021 & 0.779 & 0.291 \\
\hline lrgov does not Granger cause lfuel & $4.332 *$ & 2.381 & 1.544 & 1.232 \\
\hline
\end{tabular}

Notes: Asterisk $\left(^{*}\right)$ indicates statistically significant at 5 percent level.

Further Evidence: Following the suggestion by Engle and Granger (1987), we further execute GVDCs experiment with the purpose to forecast the effects of fuel price shock on the respective economic sectors in Malaysia beyond the sample period. The estimated results for the GVDCs derived from the VAR model is further exhibited in Table 6. From the reported results, is has been shown that over these 24 quarters, the relative variance in lfuel is generally explained by its own shock, evidence of exogeneity.

The effects of disturbances in fuel price in some sectors have arisen after several quarters. The identified sectors include manufacturing sector, utility sector, transportation sector and government services sector. For the manufacturing sector, the contribution of the disturbances in fuel price has increased from 4.898 percent in first quarter to 16.013 percent in 24 quarters (see Panel B). Since the refined petroleum products are not the main manufactured products in Malaysia, the influences from fuel price are therefore would not immediately transfer to the manufacturing sector reflecting the slow transformation effects. Such result is similar to those reported by Jiménez-Rodriguez (2007) who claims that the greater shock is received by the manufacturing industrial sector in the United Kingdom and the United States after second year.

Similar findings were pronounced in the utilities sector (see, Panel D). As indicated by Villar and Joutz (2006), when crude oil price temporarily increased by 20 percent, the natural gas price will increase by 5 percent. This is likely to reflect the Malaysian case, where the rise of the fuel will project a positive increase to the natural gas price as well as electricity price. This would eventually transfer higher cost to 
the electricity sector and utility sector as a whole. For the transportation sector, the influence of fuel price hike is likely to increase the transportation cost embedded in the operating activities. For the remaining sectors, the impacts are quite marginal in the 24 quarters period. For instance, the impact of fuel price on the government services sector is marginal, as fuel is not considered as an intermediate input.

Table 6: Further Evidence

\begin{tabular}{|c|c|c|c|}
\hline \multirow{2}{*}{$\begin{array}{l}\text { Percentage of variations in } \\
\text { Panel A: }\end{array}$} & \multirow{2}{*}{ Horizon (quarters) } & \multicolumn{2}{|c|}{ Due to innovation in: } \\
\hline & & $\Delta \operatorname{lrmin}$ & $\Delta$ lfuel \\
\hline \multicolumn{4}{|c|}{ Quarters relative variance in: $\Delta$ lrmin } \\
\hline & 1 & 99.681 & 0.319 \\
\hline & 4 & 98.620 & 1.380 \\
\hline & 8 & 98.709 & 1.291 \\
\hline & 24 & 99.046 & 0.954 \\
\hline \multicolumn{4}{|c|}{ Quarters relative variance in: $\Delta$ lfuel } \\
\hline & 1 & 0.001 & 99.999 \\
\hline & 4 & 1.639 & 98.361 \\
\hline & 8 & 2.864 & 97.136 \\
\hline & 24 & 3.690 & 96.310 \\
\hline Panel B: & & $\Delta \operatorname{lrmfc}$ & $\Delta$ lfuel \\
\hline \multicolumn{4}{|c|}{ Quarters relative variance in: $\Delta \mathrm{lrmfc}$} \\
\hline & 1 & 95.102 & 4.898 \\
\hline & 4 & 90.738 & 9.262 \\
\hline & 8 & 86.710 & 13.290 \\
\hline & 24 & 83.987 & 16.013 \\
\hline \multicolumn{4}{|c|}{ Quarters relative variance in: $\Delta$ lfuel } \\
\hline & 1 & 2.463 & 97.537 \\
\hline & 4 & 2.438 & 97.562 \\
\hline & 8 & 2.452 & 97.548 \\
\hline & 24 & 2.453 & 97.547 \\
\hline Panel C: & & $\Delta$ lrcons & $\Delta$ lfuel \\
\hline \multicolumn{4}{|c|}{ Quarters relative variance in: $\Delta \operatorname{lrcons}$} \\
\hline & 1 & 95.888 & 4.112 \\
\hline & 4 & 95.722 & 4.278 \\
\hline & 8 & 95.186 & 4.814 \\
\hline & 24 & 94.987 & 5.013 \\
\hline \multicolumn{4}{|c|}{ Quarters relative variance in: $\Delta$ lfuel } \\
\hline & 1 & 4.487 & 95.513 \\
\hline & 4 & 3.918 & 96.082 \\
\hline & 8 & 3.749 & 96.251 \\
\hline & 24 & 3.576 & 96.424 \\
\hline Panel D: & & $\Delta$ lrutilities & $\Delta$ lfuel \\
\hline \multicolumn{4}{|c|}{ Quarters relative variance in: $\Delta$ lrutilities } \\
\hline & 1 & 94.934 & 5.066 \\
\hline & 4 & 91.559 & 8.441 \\
\hline & 8 & 86.522 & 13.478 \\
\hline & 24 & 81.384 & 18.616 \\
\hline \multicolumn{4}{|c|}{ Quarters relative variance in: $\Delta$ lfuel } \\
\hline & 1 & 9.584 & 90.416 \\
\hline & 4 & 13.303 & 86.697 \\
\hline & 8 & 14.243 & 85.757 \\
\hline & 24 & 14.422 & 85.578 \\
\hline
\end{tabular}




\begin{tabular}{|c|c|c|c|}
\hline Panel E: & & $\Delta$ lrtransport & $\Delta$ lfuel \\
\hline \multicolumn{4}{|c|}{ Quarters relative variance in: $\Delta$ lrtransport } \\
\hline & 1 & 94.608 & 5.392 \\
\hline & 4 & 90.243 & 9.757 \\
\hline & 8 & 85.610 & 14.390 \\
\hline & 24 & 81.334 & 18.666 \\
\hline \multicolumn{4}{|c|}{ Quarters relative variance in: $\Delta$ lfuel } \\
\hline & 1 & 1.149 & 98.851 \\
\hline & 4 & 1.227 & 98.773 \\
\hline & 8 & 1.292 & 98.708 \\
\hline & 24 & 1.285 & 98.715 \\
\hline Panel F: & & $\Delta \operatorname{lrfin}$ & $\Delta$ lfuel \\
\hline \multicolumn{4}{|c|}{ Quarters relative variance in: $\Delta$ lrfin } \\
\hline & 1 & 99.617 & 0.383 \\
\hline & 4 & 99.565 & 0.435 \\
\hline & 8 & 99.591 & 0.409 \\
\hline & 24 & 99.704 & 0.296 \\
\hline \multicolumn{4}{|c|}{ Quarters relative variance in: $\Delta$ lfuel } \\
\hline & 1 & 1.773 & 98.227 \\
\hline & 4 & 2.680 & 97.320 \\
\hline & 8 & 2.726 & 97.274 \\
\hline & 24 & 2.641 & 97.359 \\
\hline Panel G: & & $\Delta$ lrgov & $\Delta$ lfuel \\
\hline \multicolumn{4}{|c|}{ Quarters relative variance in: $\Delta \operatorname{lrgov}$} \\
\hline & 1 & 99.897 & 0.103 \\
\hline & 4 & 99.803 & 0.197 \\
\hline & 8 & 99.312 & 0.688 \\
\hline & 24 & 96.799 & 3.201 \\
\hline \multicolumn{4}{|c|}{ Quarters relative variance in: $\Delta$ lfuel } \\
\hline & 1 & 0.056 & 99.944 \\
\hline & 4 & 0.026 & 99.974 \\
\hline & 8 & 0.012 & 99.988 \\
\hline & 24 & 0.008 & 99.992 \\
\hline
\end{tabular}

Notes: The columns in italic represent the impact of their own shock or innovation.

\section{Concluding Remarks}

This paper set up to examine the relationship between domestic petrol price and the 10 major economic sectors. The paper, which is exclusively empirical in nature, leads us to several important conclusions. First, out of 10 economic sectors, only the agriculture sector, trade sector and other services sectors have a co movement with fuel prices. Second, the significant coefficient for ect in the sectoral equations imply that that fuel price is the leading variable for these three economic sectors in the long run. Third, through the standard Granger causality test, unidirectional causality running from mining sector to fuel price is discovered. Fourth, since most of the economic sectors in Malaysia are not cointegrated with petrol price, we further adopt GVDCs experiment on the non-cointegrated sectors. The GVDCs allow one to put the perspectives of relationship between oil prices and the economic sectors. Overall, the results show that the fuel price is the relative exogenous variables in this study suggesting that the fuel price is able to influence some of these sectors over a longer period.

From the empirical investigation, we acknowledge the function of domestic fuel price in affecting the economic sectors in Malaysia. This rather implies that it is important to consider not just whether oil prices increases (internationally or domestically) or decline (and by how much) but also the environment in which the movement takes place. With the fluctuation of international oil prices, the challenge ahead 
for Malaysia in order to attain sustainable economic growth is crucial. In the sense, proactive agenda should be formulates to ensure efficient coordination in the future scenario of the oil prices. This includes the innovation in energy efficient technologies and upgrading existing equipment in order to reduce dependency on crude oil.

Malaysian government actively pursues the development of renewable energy (RE) since 1999 with the adoption of the Fifth Fuel Diversification Policy in the eighth Malaysian plan (EPU, 2001). According to Gan and Li (2008) after the recognition of RE as the fifth fuel in Malaysia, a numbers of project were implemented. This includes the projects like Small Renewable Energy Power Program (SREP), BioGen and National Biofuel Policy ${ }^{13}$. Renewable energy such as biofuel from the blend of 5 percent processed palm oil and 95 percent diesel would be an alternative especially for the industrial sectors. The revenue from palm oil industry would be another option for government to reduce the subsidy burden and a stable foreign exchange rate regime. Besides, the applications of biofuel, the utilization of the hydropower, solar power and wave power would be other alternative sources. This would made beneficial for Malaysia especially in the view of decreasing fossil fuel production and increasing energy demand coupled with the increasing awareness of environmental issues, concern for increasing green house gas emissions and uncertain oil prices. Sufficient government enforcement and support in the form of regulatory framework, incentives and targets need to be established to facilitate successful RE implementation. With the energy crisis faced by the world of depleting energy sources and high-energy consumption, cooperation for the energy conservation policies among the Asian countries would be another imperative move.

\section{Acknowledgments}

The authors are grateful to an anonymous referee for helpful comments and suggestions that have substantially improved the quality of the present version. A major portion of this paper was conducted whilst the first author was pursuing her study in Universiti Malaysia Sarawak (UNIMAS). We are thankful for the comments and suggestions of the participants at the Second International Economics Conference, Brunei Darussalam, 7-8 January 2009. All remaining flaws are the responsibility of the authors.

\section{References}

Abdul Jalil, N., Mat Ghani, G. \& Duasa, J. (2009). Oil Prices and the Malaysia Economy. International Review of Business Research Papers, 5(4), 232-256.

Bank Negara Malaysia. Monthly Statistical Bulletin, Various Issues, Bank Negara Malaysia.

Bauer, P. W. \& Byrne, S. M. (1991). The Sectoral and Regional Effects of Oil Shocks: Who's Over a Barrel? Economic Commentary, Federal Reserve Bank of Cleveland, Issue Jan 15.

Bernanke, B. S. (1983). Irreversibility, Uncertainty, and Cyclical Investment. Quarterly Journal of Economics, 98(1), 85-106.

Brown, S. P. A. \& Yucel, M. K. (2002). Energy Prices and Aggregate Economic Activity: An Interpretative Survey. The Quarterly Review of Economic and Finance, 42(2), 191-208.

Chang, Y. \& Wong, J. F. (2003). Oil Price Fluctuations and Singapore Economy. Energy Policy, 31(11), $1151-1165$.

Cunado, J. \& de Gracia, F. (2003). Do Oil Price Shocks Matter? Evidence for Some European countries. Energy Economics, 25(2), 137-154.

Cunado, J. \& de Gracia, F. (2005). Oil Prices, Economic Activity and Inflation: Evidence for Some Asian Countries. The Quarterly Review of Economics and Finance, 45(1), 65-83.

Elliott, G., Rothenberg, T. J., \& Stock, J. H. (1996). Efficient Tests for an Autoregrssive Unit Root. Econometrica, 64(4), 813-836.

EPU (Economic Planning Unit Malaysia) (2001). Eighth Malaysian Plan, 2001 - 2005, Percetakan Nasional Malaysia Berhad (PNMB).

EPU (Economic Planning Unit Malaysia) (2006). Ninth Malaysia Plan, 2006-2010, Economic Planning Unit.

\footnotetext{
${ }^{13}$ The introduction of Sarawak Corridor of Renewable Energy (SCORE) under the $9^{\text {th }}$ Malaysian Plan are also another initiative by the government for the RE strategic plan. Although it is one of the five regional development corridors, the focus is on exploration of the new and renewable natural energy resources especially for the industrial development plan.
} 
Energy Information Administration. International Petroleum Monthly, Various Issues. Energy Information Administration.

Engle, R. F., \& Granger, C. W. J. (1987). Cointegration and Error Correction Representation, Estimation and Testing. Econometrica, 55(2), 251-276.

Farzanegan, M. R., \& Markwardt, G. (2009). The effects of oil price shocks on the Iranian economy. Energy Economics, 31(1), 134-151.

Ferderer, J. (1996). Oil Price Volatility and the Macro economy. Journal of Macroeconomics, $18(1), 1$ - 26.

Gisser, M., \& Goodwin, T. H. (1986). Crude Oil and the Macro economy: Test of Some Popular Notions, Journal of Money, Credit, and Banking, 18(1), 95-103.

Gan, P. Y., \& Li, Z. D. (2008). An Econometric Study on Long-Term Energy Outlook and the Implications of Renewable Energy Utilization in Malaysia. Energy Policy 36(2), 890-899.

Gonzalo, J. (1994). Five Alternative Methods of Estimating Long Run Equilibrium Relationships. Journal of Econometrics, 60(1-2), 203-233.

Granger, C. W. J. (1969). Investigating Causal Relations by Econometric Methods and Cross-Spectral Methods. Econometrica, 37(3), 424-438.

Granger, C. W. J. (1988). Some Recent Development in a Concept of Causality. Journal of Econometrics, 38(1-2), 199-211.

Hall, S. G. (1991). The Effect of Varying Length VAR Models on the Maximum Likelihood Estimates of Cointegrating Vectors. Scottish Journal of Political Economy, 38(4), 317-333.

Hamilton, J. D. (1983). Oil and the Macro economy since World War II. Journal of Political Economy, 91(2), 228-248.

Hamilton, J. D. (1988). A Neoclassical Model of Unemployment and the Business Cycle. Journal of Political Economy, 96(3), 593-617.

Hamilton, J. D. (1996). This is What Happened to the Oil Price-Macro economy Relationship. Journal of Monetary Economics, 38(2), 215-220.

Jiménez-Rodriguez, J. (2007). The Industrial Impact of Oil Price Shocks: Evidence from the Industries of Six OECD Countries 2007. Bank of Spain, Working Paper 0731.

Jiménez-Rodriguez, J., \& Sánchez, M. (2005). Oil Price Shock and Real GDP Growth: Empirical Evidence for Some OECD Countries. Applied Economics, 37(2), 201-228.

Johansen, S., \& Juselius, K. (1990). Maximum Likelihood Estimated and Inference on Cointegration with Application to the Demand for Money. Oxford Bulletin of Economics and Statistics, 52(2), 169-210.

Kim, I., \& Loungani, P. (1992). The Role of Energy in Real Business Cycles Models. Journal of Monetary Economics, 29(2), 173-189.

Kwiatkowski, D., Phillips, P. C. B., Schmidt, P., \& Shin, Y. (1992). Testing the Null Hypothesis of Stationarity against the Alternative of a Unit Root. How Sure Are We that Economic Time Series Have a Unit Root? Journal of Econometrics, 54(1-3), 159-178.

Lee, K. C., Pesaran, M. H., \& Pierse, R. G. (1992). Persistence of Shocks and its Sources in Multisectoral Model of UK Output Growth. Economic Journal, 102(411), 342-356.

Lee, K. C., \& Pesaran, M. H. (1993). Persistence Profiles and Business Cycle Fluctuations via Disaggregate Model of UK Output Growth. Rierche Economiche, 47(3), 293-322.

Lutkepohl, H. (1991). Introduction to Multiple Time Series Analysis, Berlin: Springer-Verlag.

Masih, A. M. M., \& Masih, R. (1994). On the Robustness of Cointegration Tests of the Market Efficiency Hypothesis: Evidence from Six European Foreign Exchange Markets. Economia Internazionale, 47(2-3), 160-180.

Masih, A. M. M., \& Masih, R. (1995). Investigating the Robustness of Tests of the Market Efficiency Hypothesis: Contributions from Cointegration Techniques on the Canadian Floating Dollar. Applied Financial Economics, 5(3), 139-150.

Ministry of Domestic Trade and Consumer Affairs (2008). Kedudukan Harga Barang-Barang Kawalan yang Dikawal Harganya Secara Pentadbiran oleh Kerajaan.

Mork, K. A. (1989). Oil and the Macro economy When Prices Go Up and Down: An Extension of Hamilton's Results. Journal of Political Economy, 97 (3), 740-744.

Narayan, P. K., \& Narayan, S. (2007). Modeling Oil Price Volatility. Energy Policy, 35(12), 6549-6553.

National Economic Action Council (2005). Oil Prices and Subsidies (An Explanation).

Papapetrou, E. (2001). Oil Price Shocks, Stock Market, Economic Activity and Employment in Greece. Energy Economics, 23(5), 511-532.

Phillips, P. C. B. (1991). Optimal Inference in Cointegrated Systems. Econometrica, 59(2), 283-306.

Raguindin, M. C. E., \& Reyes, R. G. (2005). The Effects of Oil Price Shocks on the Philippines Economy: A VAR Approach. Department of Economics, University of the Philippines. 
Saari, Y. M., Radam, A., \& Abdullah, A. M. (2008). The Impacts of Increase in the Domestic Petroleum Prices on Cost of Production of Agricultural and Agro-Based Sectors. International Journal of Business and Society, 9(1), 37-52.

Said, E. S., \& Dickey, D. A. (1984). Testing for Unit Roots in Autoregressive-Moving Average Models of Unknown Order. Biometrika, 71(3), 599-607.

Schintke, J., Staglin, R., \& Weib, J. P. (2000). Higher Import Prices for Oil, Natural Gas and Mineral Oil Products: The Potential Price Effects in Individual Sectors of German Industry. Economic Bulletin, 37(12), 387-394.

Schwert, G. W. (1987). Effects of Model Specification on Tests for Unit Roots in Macroeconomic Data. Journal of Monetary Economics, 20(1), 73-103.

Valadkhani, A., \& Mitchell, W. F. (2001). Assessing the Impact of Changes in Petrol Prices on Inflation and Household Expenditures in Australia. Centre of Full Employment and Equity, Working Paper No. 01-01.

Villar, J. A., \& Joutz, F. L. (2006). The Relationship between Crude Oil and Natural Gas Prices. Energy Information Administration, Office of Oil and Natural Gas, Washington D.C.

Zind, R. G. (1999). Oil Price Movements and the Arabian Gulf Economies: A Sectoral Analysis. Resources Policy, 25(1), 59-67. 